\title{
THE
}

SilK Goddess of China

\section{AND HER LEGEND,}

BY

DR. A. TERRIEN DE LACOUPERIE, 
Ottes T. Mnasise En

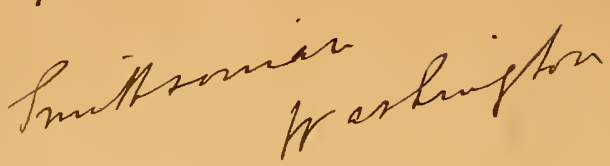

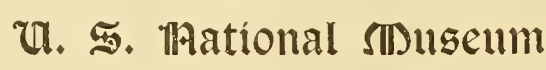

Qtis O. Aleason,

Curator of the Divisicion of Bithnolagy

zlccession 1 ro. 178793 


\section{THE}

SILK GODDESS OF CHINA

\section{AND HER LEGEND,}

BY

DR. A. TERRIEN DE LACOUPERIE,

Doct. of Phil., and of Lett., hon. caus. Lovan.;

Laur. of the Institut de France (Acad. Inscript. et Belles Lettres.)

Professor of Indo-Chinese Philology (formerly of University College, Londou);

Coll. Musée Guimet, Paris ; M. counc. Philological Society;

M. hon. Royal Asiatic Society, London; M. hon. Société Orientale, Louvain;

II. C. Peking Oriental Society; M. C. Academie de Stanislas, Nancy;

II. C. Academie des Sciences, Marseille; M. C. Societé d'Archéologie, Bordeaux;

M. Socíeté de Linguistique, Paris;

Author of The Oldest Book of the Chinese, 1882; Beginnings of writing around Tibet, 185-;

The Languages of China before the Chinese, 1887; Origin of the Chinese Civilisation

from Western Sources, 1889; Historical Description of Ancient Chinese Money, 1890;

Director of The Babylonian and Oriental Record, dc.

LONDON :

DAVID NUTT, 270, STRAND.

LUZAC \& CO., 46, GREAT RUSSELL STREET, W.C.

1891. 




\section{THE SILK GODDESS OF CHINA}

AND HER LEGEND.

SUMMARY. INTRODUCTORY.

$\$ 1$. Present worship of Si-ling she.-2. Is no proof of its genuineness.

I. Ancient Geography of Sericulture.-

\$3. Silk industry indigenous in China.-4. Attributed to Si-ling she Lui-tsu yuen-fei._5. Silk of Shan-tung in the Shu king.-6. Silk mentioned in the Yh king.-7. The Tribute of $Y i i$, the oldest description of China.- -8. Products of four provinces.- -9. Products of five provinces.-10. Candid riew to be taken of these statements.-11. Silk and cloth from Tsiu-tchou and Yang-tchou.-12. Stuff and silk from King-tchou and Yu-tchou._-13. Four instances only of silk in the Eastern provinces.-14. West and Central China had no silk.-15. Shan-si, the Chinese focus had silk on the East.-16. Late allusion in the Shi-king as to S. Shensi.-17. Poetical description of sericulture,-18. It had been introduced from the East.-19. It developed there under the Mongols and disappeared.-20. The Tchou li mentions silk only in Honan and N. Shansi.-21. The sericulture of Szetchuen is not primitive.

II. Calendaric Rules, Rites and Custoirs.

$\$ 22$. Entries about silkworms in the Brief Calendar of the Hia dynasty.23. In the Ritual of the Tchou dynasty (Tchou li).-24. In the Iueh ling of the Li ki, with reference to a sacrifice to the ancient Emperors.-25. On the Royal culture of silkworms. -26 . The Princesses like the Queen must attend to silkworms.-27. Silkworms and silk in the Shi king.-28. No souvenir of their discovery. 
III. Variuus tutelary Silits and Goddesses of silk.

\$29. Discovery of silk not mentioned in the Hi-tze nor in the : han hai king.-30. Rationalised tableau of savage life in the Li ki.-31. Sacrifice to the Sien Ts'an or First silkworms mentioned in a spurious passage of the same work.-32. Sacrifice for silkworms to the Land deity, IIIrd cent. A.D.-33. Sacrifice by the Ts'in Empress in the IV th cent. to Tsan shen i.e. the Tutelary Genius of silkworms.34. Official ceremony in 460 A.D.-35. Tague statement of the T'ung Kien Kang Muh.-36. Nothing known by tradition as to a real inventor. - 37. Tchou she, wife of $\mathrm{Wu}$-ti, $1+1$ B.c., worshipped in the Vth century.-38. Yuen yü and $Y \ddot{u}$ she worshipped in the XIth cent. -39. They belong probably to the IInd cent. A.D.--40. No ancient traces of the goddess Sl-ling she Lui tsu.

IV. Formation of the Legend of the Goddess Si-ling she Lui tso. \$41. Luitsu, a bare name in the She ki.-42. Its analysis developed into a mythological statement.-43. Given as an historical fact in the XIth century.-44. Quite unknown in earlier times.-45. Shen-nung as inventor of silk.-46. Lui-tsu, a daughter of the Si-ling clan.47. Interest at identifying the Si-ling.--48. Described in the Er-ya.49. They were in Kan-suh.

Conclusiox. $\$ 50$. Lui tsu is a case of mythography, and sericulture was a pre-Chinese industry.

\section{INTRODU CTORY.}

1. In the grounds of the Imperial Palace ${ }^{1}$ at Peking is an altar forty feet in circuit and four feet in height, surrounded by a wall ${ }^{2}$ and also a temple called the ts'en-tsan-tao, "The early silk worms'altar in the vicinity of which a plantation of mulberry trees and a cocoonery are maintained. It is dedicated to Yuenfei otherwise Firstwife in her quality of discoverer of the silkworms, ${ }^{3}$ and annually in April, the Empress worships and sacrifices to her. ${ }^{4}$ The same goddess has several important temples in Tchehkiang, one of the provinces where the silk industry flourishes, but I have no evidence to adduce as to her probable worship elsewhere. As we shall see further on, Yuen-fei is said to be the name of Si-ling-she, first wife of Huang-ti the leader of the Bak families who cirilised China.

2. Howerer deeply rooted this belief may be in the mind of the Chinese people, it cannot necessarily be looked upon as a proof of historical veracity; and some more proofs are required for it being accepted as a fact that the first leader of the Chinese and his wife, on the North-west cf China proper, some twenty-three centuries before our era, had taught the inhabitants of the Middle Kingdom, the rearing of silkworms and the silk industry.

Is there any truth in the legend, and if not what is the origin of the belief ? 


\section{Notes - -}

1) North of the bridge leading to the Kiung hwa tao island.

2) The present enclosure was put up under Yung tching in 1742, but its buildings, says W. Williams, II, 23, are now much dilapidated.

3) W. Williams, Middle Kingdom, R. Lid., rol. I, p. 71; II, 33.

4) J. H. Gray, China, vol. II, p. 220. On a fortunate day in the spring of each year, her state worship is duly solemnized by the Mandarins.---In the interesting description of Peking by the Rev. Joseph Edkins, printed in A. Williamson: Journeys in North China, 1870, vol. II, we find the following statements : "On the North side (of the lake) is a hill on an island called fiiung hwa tco, capped by a white pagoda or dagoba. Here there is an altar on the hill side to the originator of silk manufactures and to the presiding genius of the silkworm ; the altar wall is 1600 feet round and the altar itself forty feet in circuit, and four feet high. Round it are mulberry trees, and near it a tank for washing the worms. The Empress comes here annually t. feed the silkworms, which are kept in a house suitable for the purpose ; she thus isets an example of industry to the working women of the empire." Cf. p. 335. - "On a fortunate day of the ninth month, the empress, either personally or by proxy, accompanied by a train of princesses and honourable ladies, repairs to the altar sacred to the discoverer of silkworms. After sacrificing, the empress with golden, and the princesses with silver implements, collect the mulberry leaves to feed the imperial silkworms. They, then, wind off some cocoons of silk, and so end the ceremony. This rery ancient festival is considered as the counterpart of the agriculture one, observed by the emperor in the spring." M. Murrow. Hongkong Chronicle and Directory for 1865 , in J. H. Gray, China, vol. II, p. 220.

I.

3. Silk industry is in ligenous in China as the silkworm itself. It has not been brought into the country by its ancient cirilisers the Bak tribes, neither by any of the other races, like the Jungs, who also immigrated into China in remote times. We cannot be surprised therefore if the Chinese traditions about the silkworm rearing and the silk industry are by far the oldest and hitherto the only ancient ones on the subject.

4. Legend attributes the art of winding the silkworms' cocoons to the time of the first leader of the Pre-Chinese Bak tribes, while they were established as yet on the North-west borders of present China proper. This leader commonly known as Hwang-ti, but whose complete name was Nakhunte ${ }^{6}$ married four wires; ${ }^{7}$ the first of them. from the clan of $\mathrm{S}$ iling, ${ }^{8}$ and named 嫘祖 Lui-ts u, ${ }^{9}$ is the one who is said to have begun to rear silkworms. She has been deified and she is still worshipped for that reason at the (先) Sien-tsan or ancient silkmorms' altar. ${ }^{10}$ She is also called 元妃 Iuen-fei or first wife. ${ }^{11}$ We shall examine these varions 
appellatives further on $(\$ \S 4 C-45)$, so far as they cenfirm or weaken the veracity of the legend, and we shall see that it is nothing more than an instance of mythology caused by the ideographism of the written characters.

5. The first reference to silk or better silk-cloth in historical documents is that which occurs in the second chapter of the $\mathrm{Book}$ of $\mathrm{History}{ }^{12}$, the Canon of Shun, where the Chinese ruler is said to have made a tour of inspection among the fiefs eastward as far as the mountain of Tai, otherwise the Taishan in Shantung W., the most famous of the sacred hills of China. Shun made there a certain number of regulations, including one concerning the san $\dot{p} e h$ or threesorts of silks. The text there is apparently corrupted and contains a difficulty which has not been cleared off either by the natije commentators or the Sinologists who have translated it. But this does not affect the san peh, as they are mentioned at the same time as the five classes of rites to be observed, the five orders of gem-tokens, and the other articles which prepared the way to the princes for their audience from the Chinese ruler. The oldest sons of chiefs were bound to hold silk of a deep red, the sons of the three highest officers silks of a reddish black, and the chieftains of small attached territories yellow silks. There is perhaps in this explanation much of later rites, although a distinction of some sort was then and there established for three sorts of plain silk cloth as articles of introduction, and the unparalleled stableness of the rites and institutions of the Kingdom Beneath-Heaven allows the explanation of many ancient manners and customs by the peculiarities of the later ones. An interesting characteristic of the foregoing statement of the Shu King is that the regulation concerning the three classes of silk's presents was made when the Chinese ruler went to the East of his dominion, in the modern province of Shantung which has always been known for its silk industry, as we shall see further on.

6. An older reference to $p e h$ or plain silk, if no substitution of character has been made in

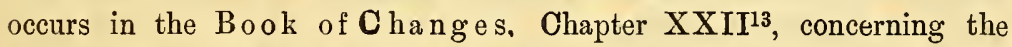
symbol $P i$ and Fen, where it is spoken of shuh peh, bundle of silk cloth.

7. The $T \ddot{u}$ Kung, or Tribute of $\mathrm{Y} \ddot{\mathrm{u}}$, the oldest geographical document of Chinese literature, describes the chief products of the country according to its divisions under and outside the Chinese rule. This distinction which has not as yet received the attention it deserves is somewhat con- 
cealed from view, and the nine tchiou are all enumerated, as if to convey the idea that every one in its entirety was under the Chinese dominion. The sole difference consists in the use of one or the other of two words when speaking of the products of the land, $W u$ and $K u n g^{14}$. The first means : revenue, contribution of revenue, assess; while the second, $K u n g$, is to present as tribute to a superior, to offer up; showing therefore that the products which are $w u$ are those of Chinese or others, subjects to the dominion of the son of Heaven, while the products which are Kung come from foreigners and non-suojects and may or may not be brought according to treaties, homage, convenience or for trade purposes.

The Iü Kung, once noticed this distinction, is most instructive about the real extension, limited at that time, of the dominion of the Chinese, and it shows which products and industry were then in the hands of the native population, and those of the Chinese themselves.

8. In the province of Kitchou, i.e. roughly the present Shansi, and the real seat of the Chinese no special products or industries are spoken of.

In Fentchou, to the east of the preceding, a part of Tchihli W. and C., the offerings consisted of lacquer, silk and ornamented stuffs ${ }^{15}$ in round bamboo baskets.

In Tsingtchou, roughly Shantung, salt and a fine grass cloth were presented from the sea-shore, silk.16 and hemp from the ralleys of the Tai, and baskets of silk of wild-silkworms ${ }^{17}$ from the Lai tribes.

In Tsiutchou, i.e. Shantung S., and Kiangsu ${ }^{18}$, the aboriginal tribes of the Hwai brought oyster fearls and fish, and baskets of reddish black and undyed fine fabrics ${ }^{19}$.

9. In Iangtchou, i.e. the region around and south of the mouths of Yangtze, the articles presented were various and included fabrics and cauries ${ }^{20}$.

In Kingtchou, W. of preceding, i.e. Hupeh and the adjoining South, the offerings included baskets of reddish black and crimson stuffs ${ }^{21}$, with trings of irregular pearls 22 .

In Yutchou, corresponding to Honan, baskets ${ }^{2.3}$ filled with fine fabrics, and fine floss-silk, were presented ${ }^{24}$.

In Liangtchou, which corresponded to the W. of Honan and Hupeh with the North of Szetchuen, there'were no offers of silk, although other products were numerous ${ }^{25}$.

The same thing may be said of the last province, Iungtchou, com- 
prising Shensi and the adjoining west which produced no silk, nor other products worth mentioning, with the exception of several sorts of precious stones; offers of hair-cloth and skins were made, but only by the foreign tribes of the mountainous west ${ }^{26}$.

10. The present résumé is an unșophisticated account of the textile industry in the parts of China proper known to the authors of the YüKung. It is by far less glowing a description than some published translations would lead their readers to suppose. The cause of this difference is not far to seek. We have confined ourselves to the bare statements of facts, without indulging into inferences which are not supported by positive words to that effect. Although the terseness and vagueness of the Chinese texts leave much to the reader's mind to infer, we are of opinion that it is a great error to derelope the meaning of the characters beyond their natural and commonly received acceptation. We must not follow the Chinese commentators in their erroneous system of considering and interpreting all the ancient statements in a roseate and glowing view. In Yentchou, for instance, the offers consisted of lacquer, se or silk and tchehwen or woven ornaments. This is the literal translation, but native commentators, in their constant endeavours to beautify and make the utmost of all that concerns the deeds of their ancients, have suggested that these words implied fabrics of the highest quality as handiwork and material27.

11. In Tsiu-tchou we have noticed offer's by the native tribes of the Hwai of fine fabrics reddish black and undyed. The terms are hiuen sien kao, meaning litteraliy : reddish black ${ }^{28}$ fine fabrics and raw. Sien is properly small, fine like silken fibres ${ }^{29}$, and it applies also to 2 cloth wore with a black warp ${ }^{30}$, and white woof ${ }^{31}$. Now commentators of the Shu King have improved upon that and we find these three words magnified into blacksilks and chequeredsarcenets in Medhurst's 32and by: deep azure silks, and other silken fabrics, chequered and white in Legge's translation ${ }^{33}$.

In Yang-tchou, the region bordering the maritime provinces of the south east, the text says that the offers consisted in teheh pei, fabrics and cauries, which are magnified into: woven ornamented silks in Legge's translation ${ }^{34}$, and more soberly rendered by : weaving cotton in Medhurst's ${ }^{\mathbf{3 5}}$.

12. Offers were made from King-tca $u$ in hiuen hiun or reddish black and crimsonstuffs. The two Chinese symbols mean simply deepazure and bright-red-three-times-dyed ${ }^{36}$, and there is no statement as to 
what application these colours had received. Commentaturs of course made it to be silk and accordingly we hear of reddish-black and purple silken fabrics' and of 'black and red silk' in Legge's and Medhurst's renderings ${ }^{37}$.

From Iutchuu, offers were made in Sien Kw'ang or fine-fabrics and fine-floss-silk. The proper meaning of sien has previously been ascertained, and as to that of $k w^{\prime}$ ang there is a sufficient amount of proofs independent of this very case to justify the foregoing rendering ${ }^{38}$. In Medhurst's translation the two words become :.different coloured floss silk and silky cott on, and in Legge's : fine silken fabrics and fine floss sil k $\mathrm{k}^{39}$.

13. This critical surrey shows how the four genuine statements concerning production of silk referred to in the $Y \ddot{u}$ Kung, have been magnified into nine by uncritical, if patriotic, commentators whom several European scholars have blindly followed. A criticism of the original Chinese texts according to western method is the first thing to be done by Sinologists before trusting statements of native scholars of the Middle Kingdom.

14. Silk culture was then restricted to a much more limited area than is commonly believed, and flourished only in the East. The present provinces of Shensi, Szetchuen, Hupeh, \&c. were not silł-producing regions, although in the last-named province the weaving industry was re-known, and may have employed silk in the manufacture of its famo $\mathrm{u}_{\mathrm{S}}$ cloth, reddish-blact and crimson, while in the two first-named provinces woollen cloth was the object of a regular industry. Tchilli, Shantung, and Honan were producing silk. In the two first provinces silk was an indigenous product, especially in the east of Shantung, where it was in the hands of the aboriginal population.

15. It is worth noticing that Shansi province does not appear in the preceding list, as producing or non-producing-sill. The negative evidence. however, is no proof, as the whole province was then the real seat of the Chinese, and no list whatever of products is given therefrom, perhaps because they were all assessed or wu goods. We do not seel justified to infer from that silence that the Chinese of the region were uo silk culturists. The importance they attached to silk vouches of their sure efforts at introducing silkworms in Shansi should they not have found some therein. In the same document we hare just examined, there is a positive statement to that effect with reference to a part of Yentchou (Tchihli W. and C.): "the mulberry ground haring been supplied with 


\section{of Chisa.}

silkworms, the people descended from the hills and dwelt in the plains." 40

16. The Book of Poetry might be referred to as a proof that silk culture was in olden times a regular occupationin the south of Shensi, in the $P^{\prime}$ in and $K$ 'i countries, the seats of the Tchou tribes for some five hundred years previously to the establishment of their dynasty eastrards at HaoKing, later Si-ngan, and at Loh-yang. The celebrated Duke of Tchou wrote a long ode describing the ancient manners and ways of his countrymen. ${ }^{41}$ The tale is supposed to be told by an aged yeoman, but no allusion is made to the date nor to the name of the region of the scene. But as the spokesman alludes to the Fire-star or Heart of Scorpio passing the meridian in the seventh month, an astronomical fact which was correct in the twelfth century, while it was not so 600 years previously, and as the numeric order of the months quoted therein is yet that of the Hia dynasty, if follows that the descriptions in the Ode refer to the condition and occupations of the Tchou people during the age immediately preceding the foundation of their dynasty.

The verses concerning the silk-culture are interesting to read:-

With the spring days the warmth begins

And the oride utters its song.

The young women take their deep baskets̃,

And go along the small paths

Looking for the tender (leaves of the) mulberry trees.

In the silkworm month they strip the mulberry branches of their leaves,

And take their axes and hatchets,

To lop off those that are distant and high;

Only stripping the young trees of their leaves.

In the seventh month the shilke is heard.

In the eighth month, they begin their spinning;

They make dark ${ }^{42}$ fabrics and yellow.

Our red manufacture is very brilliant,

It is for the lower robes of our young princes.

18. The song of the Oriole gave notice of the time to take the silkworms in hand, and the note of the shrike was the signal to set about spinning. The expression used here for that operation, $t$ sih, $(8004)$ is that specially appropriate to the twisting of hemp. The commentators explain the following verse as referring to the dyeing operations on both the woven silk and the $\operatorname{cloth}^{43}$. But as silk work was an occupation more noble, so to say, than hemp and dolichos work, it was to be expected from the commentators that they should impress upon their readers that silk was alluded to in the passage in question. Anyhow, in face of proof to the contrary derived previously from the $Y_{\ddot{u}-k u n g}$, it cannot be inferred from these verses that silk culture was indigenous in Shensi, and known there 
in the most ancient times, as it may have been and most probably was introduced thexein from the eastern provinces by the Chinese as they did in Shansi.

19. Marco-Polo (1265-1289) mentions repeatedly abundance of silk in Shansi and Shensi, whereas now there is next to no silk grown in these districts.44 In the highly interesting Reports on Silk drawn by the officials of the Chinese Imperial cnstoms, hardly any reference is made to silk of these provinces. The change of climate which has been spoken of Shensi in and southern Shansi by geologists ${ }^{45}$ may have caused this result. A commercial change may have come to the same. The climate of the two aforesald provinces apparently, was not at any time favourable to the spread of silk worms unless specially reared and this may be the simple explanation of the divergence in the statements.

20. The Ritual of the T chou dynasty has a special book, the 33rd, concerning the officers in charge of the different regions of the dominion, and in which the various products of the nine-provinces are enumerated. It is the counter part at a later date of the statements on the same subject which we have found in the Y $\ddot{u}$ Kung. The information therein confirms the facts elicited, from our unsophisticated resumé of the older document, on the limited area of silk culture in ancient times. Of the nine provinces, two only were producing the precious textile. $y u-t c h o u$ corresponding to the same province than that of the same name in the Yü Kung i.e. roughly to Honan, continued to produce silk and also lacquer, and hemp. with the addition of bamboo. $P$ ing $t c h o u^{46}$ corresponding to N. Shansi and previously included in $K i$ tchou produced linen and silk ${ }^{47}$. And this is all48. The culture of silk in the hands of the native tribes mentioned in the $Y u$ Kung are out of reckoning in that work.

21. The Szetchuen province has been for long a silk producing land as shown by the history of the country ${ }^{49}$ written about the Christian era by Yang-Hiung the philologist ${ }^{50}$ who was himself a native from there. One of the early kings is called the sil k-w o r m s rea r e $\mathrm{r}^{51}$ and therefore might be looked upon as haring introduced then in his country. He had easily obtained some from the Chinese. This king seems to have lived some fire hundred years before the Christian era. The geography of the Han period ${ }^{52}$ mentions a $T$ san ling or Silkw o rm's $\mathrm{r}$ ange in the Shuh Kiun. which shows that silk culture had became prosperous. The silence of the $Y_{\ddot{u}}$ kung showing the absence of silk products in the Liang tchou combined with the information to be derived 
from the statements just quoted, must bè taken together as a precise indication that sericulture was not practiced in that part of China proper during the earliest period. Therefore it was special only to the eastern part of the country.

\section{Notes-}

5) Cf. T'so chuen Siang Kung, year xIv, 1. and The Languages of China before the Chinese, par. 28 and 89.

6) On this name cf. my special paper: Onomastic similarity of Nakhunte of Susiana and Nakhunte of China: B \& O,R. IV. pp. 256-264.

7) Hwang P'u-mi,Ti wang she ki,-Taiping yü lan, kiv.135, fol.7 verso. Hwang-ti had twenty five children by his four wives. In the Persian legends Kaïomars, the first king, had also twenty five children, according to the Bundehesh.

8) Si-ling, (9852-11803) i.e. West Hills. The Nos. in brackets are throughout those of the Chinese characters as arranged in the old Dictionary of Basile de Glemona edited by de Guignes (1813), and in the Dictionarium Linguce Sinicce, A.M.D.G., Ho-kien, Jan. 1877. It is the most convenient system of indicating the characters when they are not a vailable.-The Si-ling hare not been identified as yet, because those of central China have no possible relation with the former, as they wero so named as late as the Han dynasty. The Si-ling of Nakhunte's time must be looked for along the Knenlun range.

9) Litt. Grand-mother of thread, a rather ominous meaning,

10) W. Williams, Middle Kıngdom. Rev. Edit, I. 7I, II. 33.---It must be remarked that Lui-tsu was the mother of Tchang-y, who was sent away near the Joh water, as reported by Szema-Tsien's She-kl, and other works.

11) In Hwang P'u-mi's work quoted supra, note 7.

12) Sh" King, Shun tien, 8.

13) Yh King, Kwa XXIl. The character is (10450).

14) 賦 $W u$ and 貢 Kung.

15) Written: 系系 se and 織 文 tcheh wén.

16) Written: se (7853)as in preceding note.-Also: lead, pine-trees, and curious stones.

17) Written: Yen-se.(1076-7853). Such worms exist as yet in theprovince. Cf. Dr. Fauvel : The wild silkworms of the Province of Shantung, in China Review, vol. VI, p. 89.

18) Its articles of tribute were earth of fire different colours; with the variegated feathers of pheasants from the valleys of the $\mathrm{Yu}$; the solitary dryandra from the South of Mount $\mathrm{Yh}$; and the sounding stones that seemed to float, near the banks of the Sze.

19) Written : hiuen sien kao (6051-8078-12656).

20) Written: Tcheh Pei (8021-10408).-And also: gold, silver and copper; yao (5981) and kuen (5948) stones; bamboos small and large ; elephants' teeth, hides, feathers, hair and timber ; and from islanders, garments of grass. Also small oranges and pummeloes.

21) Written : hiuen hiun (6051-8087).

$22)$ Also : feathers,hair, ivory and hides; gold, silver and copper ; the tch'un tree, wood for bows, cedars and cypresses ; Kw'er and lu bamboos, hoo-tree wood, three-ribbed rush, \&c. 
23) And also lacquer, hemp, a finer and coarser hempen cloth; also occasionally stones for polishing sounding-stones.

24) Written . (8078-2568) Sien lkwang.

25) The offered products consisted in sonorous stones, iron, silver, steel, stones for arrowheads, and sounding stones, skins of bears, great bears, foxes, jackals, and articles woven with their hair.

26) The sole articles offered, were hair-cloth, and skins from the tribes of Kuenlun, Sihtche, and K'iuson.

27) Meddhurst, The Shoo King, p. 92. translates . stuffs of various colours.-Legge, Chinese Classics, vol. III, p. 99, has : woven ornamental fabrics.-Panthier, Chine Ancienne, p. 48, translates: 'tissus de diverses couleurs.'

28) Hiuen is properly a black hue with a flush of red in it.

29) Shwoh Wen, sub verb.

30) Wells Williams, Syll. Dict.p. 800 .

31) K'anghi tze tien, $120+17$ fol. 65 verso, quoting the Li Kien tchuan, a late work. A commentator of the Tsien Han Shu explains it as : fine cloth.

32) The Shoo King, p. 96.

33) Chinese Classics. vol. III, p. 107.-Pauthier, Chine, p. 48, translates : 'soie rouge, noire, et blanche.'

34) Ibid. p. 111.

35) The Shoo King, p. 98.

36) Cf. Er-ya--Shwoh Wen.-T'chou li, Kao kung ki.

37) Chinese Classics, vol. III, p. 116.--The Shoo king, p. 101. Pauthier, Chine, p. 49, translates : 'pieces de soie noire et rouge.'

38) The Shwoh wen explains it by $N a$. ravelled silk, and the $Y \ddot{u}$ pien by Mien, $\mathrm{n}$ e w silk. Cf. Kanghi tzetien, $120+15$, fol. 63 .

39) The Shoo King, p. 102--Chinese Classics, vol. I1I, p. 119.--Pathier, Chine, p. 49, translates: 'toiles fines et fil de coton.'

40) Shu King, Yü Kung, III.

41) This Ode Tih yueh classified in the She King as the first among those of Pin, is supposed by the commentators to refer chiefly to the manners of the first settlers in Pin under the rule of Duke Liu. But the piece does not bear any internal evidence of this contention. Neither Pin nor the Duke Liu are mentioned therein.

42) The term hiuen here translated $\mathrm{d}$ ar k $1 \mathrm{~s}^{\mathrm{t}}$ the same as note 28.

43) Cf. James Legge, Chrnese Classics, vol. IV, pp. 228-9, and notes.

44) In Shansi, only little silk is produced, namely about 700 piculs annually in Raw silk, of which 500 piculs are wild. Cf. China. Imperial Maritime Customs II.--Special Series : No, 3, Silk, 1881, pp. 20-21. Nothing is said of silk in Shensi. M, Natalis Rondot of Lyon, in the statistics he has compiled from older documents for the Exhibition of 1878 in Paris has included the names of Shansi and Shensi in his figures. The latter province however is referred to only for Oak silkworms.

45) Notably by F. von Richtofen; cf. H. Yule. The book of Ser Marco Polo, vol. II,p.18.

46) Tchou-li, Tchih fang she, XXIII, fol. 17.-Ed. Biot, Le Tchou-li ou Rites des 'Tchéou, 1851, vol. II, p. 269.

47) The commentary of $\mathrm{Y}$-fu says that this prorince which existed at 
the time of Shun when he devided the Empire in 12 provinces, was included by the great $\mathrm{Yii}$ in the $\mathrm{Ki}$ tchou, and restored by the 'T.chour.

48) Ibirl. fol: 49, and page 275. Jid. Biot, forgetting the previous statement about the $\mathrm{Yu}$ tchou, remarks how curious it is that silk should be attributed only to the North of the Empire, and supposes that it may indicate an exportation of silk. The learned author was labouring under the glowing and exagerated explanation put forth by the commentators of thr $Y u k u n g$, and the wrong impression that silk culture was much more extensive than it really was in olden times.

49) Shuh wang pen tsi.--Cf. also the Tcheng-tu ki.

50) On this great scholar ef. T. de L., The languages of China before the Chinese, \$\$ 42-53.

51) Tsang t'sung she (9628-1108-48:0).

52) Tsien Han shu, T'i li tchi.

II.

\section{Clalendaric Rules, Rites and Custums.}

2:2. A remarkable document, the Brief Calendar of the Hia dynasty ${ }^{53}$, which internal evidence shows to have been compiled about 2000 ब.c., $\checkmark$ proves how great was already at that time the importance attached to silkworm rearing. There are in it three special entries, as follows :

1, 30. " (In the second month). Is plucked"54 the Ailanthus glandulos $a^{55}$. Multitudes of small insects (silkworms?) tap the eggshells (which contain them).

1. 38. In the third month, gathered are the mulberry leaves.

1. 44. Lasses and Lads begin attending the silkworms.

1. 45. And take in hand the rearing-house "business 56 ."

These calendaric statements of olden times, assumed afterwards the value of official regulations.

23. The Ritual of the Tchou dynasty ${ }^{57}$, which we have previously quoted rules that " in the middle of spring, the Nei-tsai invites the Queen to inaugurate the rearing of silk-worms in the Northern suburb to make the sacrificial robes ${ }^{58}$." Nei tsai is the title of the special officer of gorernment in charge of the part of the palace occupied by the queen, wives and concubines of the Son of Heaven. There are besides two officials, the M a nage r of silk or Tien se and the Ma nager of flax or Tien si, who keep these textiles in stores and distribnte them for embroidering and wearing, and receive them when worked out ${ }^{59}$.

24. In the third century в.c., Lui Pu-wei (D. 237 B.c.) or one of his collaborateurs, compiled for his collection entitled Tchun tsiu, the monthly regulations, similar to the Brief Calendar of the Hia dynasty, but with all the modifications and additions which had occurred in the meantime. This precious record, named Yueh ling or $\mathbf{M}$ o $\mathrm{n}$ thly $\mathrm{rules}$ was 
afterwards introduced into the $\mathrm{Record}$ of $\mathrm{Ri}$ tes or $L i k i$, where it forms the fourth book ${ }^{60}$, by a renowned scholar named Ma Yung (79-166 A.D.) "In the last month of spring ${ }^{61}$, - the son of Heaven presents robes yellow like the young leaves of the mulberry tree to the ancient $T i$ or divine ruler62." As the queens were not called $T i$, this may indicate a sacrifice not to the queens, but to the ancient Emperors, if not perhaps to Huangti himself, looked upon as the initiator of the silk-worm $\checkmark$

F industry. "In the same month,---the queen after vigil and fasting, goes in person to the eastern fields to work on the mulberry trees. She orders the wives and younger women (of the palace) not to wear their ornamented dresses, and to suspend their woman's work, thus stimulating them to attend to the business with the worms. When this has been completed, she apportions the cocoons, weighs out (afterwards) the silk, on which they go to work, to supply the robes for the solsticial and nther great religious services, and for use in the aucestral temple; not one is allowed to be idle ${ }^{63}$."

"In the first month of summer,---when the work with the silk-worms is over, the queen presents her cocoons; and the tithe-tax of cocoons generally is collected, according to the number of mulberry trees; for noble and mean, for old and young there is one law. The object is with such cocoons to provide materials for the robes to be used at the sacrifices in the suburbs and in the ancestral temple ${ }^{64}$."

25. Other parts of the same Ritual, the Li ki, refer to sericulture. They are not nninteresting to read. In the chapter on $T s i-y$ or $\mathrm{M}$ e a ning of sacrifices ${ }^{65}$, it is said :

Anciently the Son of Hearen and the feudal lords had their own mulberry trees an $l$ silkworms' house; the latter built near a river, ten cubits in height, the surrounding walis being topped with thorns and the gates clused on the outside. In the early morning of a very brighif day, the ruler, in his skin cap and the white skirt, divined for the most auspicious of the honourable ladies in the three palaces of his wife, who were then employed to take the silkworms into the house. They washed the seeds in the stream, gathered the leares from the mulberry trees, and dried them in the wind to feed the worms.

When the (silkworm) year was ended, the honourable ladies had finished their work with the insects, and carried the cocoons to show them to the ruler. They then presented them to his wife, "Will not these supply the materials for the ruler's robes ?" She forthwith received them, wearing her head dress and the robe with pheasants on it, and 
afterwards caused a sheep and a pig to be killed and cooked to treat (the ladies). This probably was the ancient custom at the presentation of the cocoons.

Afterwards, on a good day, the wife rinsed some of them thrice in a vessel, beginning to unwind them, and then distributed them to the auspicious and honourable ladies of her three palaces to (complete) the unwinding. They then dyed the thread red and green, azure and yellow, to make the variously coloured figures on robes. When the robes were finished, the ruler wore them in sacrificing to the former kings and dukes; - all displayed the greatest reverence.

26. In the following chapter T'se t'ung containing a s u mma ry acc o unt of sacrifices, it is said ${ }^{66}:$ "....... the Son of Heaven himself guided the plough in the Southern suburb, to provide the grain for the sacriticial ressels; and the queen looked after her silkworms in the Northern suburb, to provide the cap and robes of silk. The princes of the States guided the plough in their eastern suburb, also to provide the grain for the sacrificial vessels, and their wives looked after their silkworms in the northern suburb, to provide the cap and robes of silk."

27. Although silkworms and silk are not unfrequently mentioned in the Book of Poetry, no allusion appears anywhere to a 'l'utelary spirit of silkworms.

Silk was a great luxury and its cultivation cannot have been extensively used. It is severally spoken of as the material of embroideries.

In Tchih-li, great officers wore lamb-skins and sheep-skins with five braidings of white sillk ${ }^{67}$, while young princes are said to have been angling with lines made of silk thread68:

A Marchioness of Wei (S. Shansi) about 750 в.c. wears a green upper robe in silk with a yellow lining69. Great officers of the same state have pennows on staffs with ox-tails and white silk cords or ribbons ${ }^{70}$.

Silk was used also for girdles ${ }^{71}$, and occasionally for string of bows ${ }^{72}$; reins are praised when they are glossy like silk ${ }^{73}$. Officers wore silk robes for sacrificial ceremonies ${ }^{74}$.

In all these cases the written symbol to denote silk is the special one for it, (7853) se and no misapprehension is possible. But there are other terms which also appear in the Book of P o etry.

A dress of $\mathrm{th}$ in und yed silk 系高 $k \alpha o$ is spoken of once in an ode where the poet speaks of his lady-love: $s \mathrm{~h} e \mathrm{in}$ the $\mathrm{thin} s \mathrm{ilk}$ and the light blue coiff u r e $\mathrm{e}^{75}$.

Princes of state in sacrificing wore an inner robe made of white silk, 
with a vermilion collar. On this were embroidered the axes of authority. and it was fitted also with a hem or edging of rermilion coloured silk $\mathrm{k}^{76}$, $\mathrm{Su}\left(77_{86}\right) \mathrm{wh}$ it e silk is the expression used in the ode speaking of this robe, and also in another ode to describe the strings in white silk of the ear-stoppers of a bridegroom ${ }^{77}$.

28. These various references show how important was the valuerattachedto silk and silkworms amongst the ancient Chinese. Should any invention or discovery of the sort had been made by them at a certain time, the souvenir of the event would have preserved in one or the other of these ancient books. But nothing is said as if silkworm rearing had ever existed.

Notes

53) The Li-ki, Bk. TII or Li yun, sect. I, par. 5, puts in the words of Confucius that he found himself "The Seasons of $\mathrm{Hi}$ a" a work which was preserved in the state of $K^{\prime} i$ in charge of the traditions and sacrifices concerning the Hia dynasty.

5.4) This grammatical cunstruction, peculiar as it is, is that which is referred to in Les langues de lr chine avant les chinois. par. 12.

55) It was used at sacrifices and as food for silkworms.

56) Hia sico tcheng. Cf. R. K. Douglas: Early Chinese texts. I. The Calendar of the Hia dynasty, 1852, pp. 29, 32 and 34. The end of the last statement is translated : . . . the rearing-palace matters.

57) Tchou-li, ViI, 10 : trad. Biot; vol. I, p. 146.

58) The commentators infer from this, in comparison with the statements of the Hia sicio tcheng, and of the Yueh ling which see infici, that there existed since olden times an official building for the silkworms, otherwise an official Magnanerie.

59) Tchou $L i$, VII, 36-41.

60) The Li ki, trad. Legge ; introd. pp. 7 and $20-21$.

61) On the third day of the third month ; according to Dr. I. de Groote, ef. following note.

62 Yueh ling, III, 6 ; in Li ki, trad. Legge, rol. I, p. 263. Dr. J. J. de Groote: Les fêtes annuellement celebrées à Emony, vol. I, p. 203 translates it to the plural. The Chinese texts quoted in Dr. Groote, says simply that the Son of Hearen offers Kiüh robes to the ancient Ti(s ?): De Groote translates .... vêtements couleur d'aster..... Dr. Eitel, Cantonese dictionary, p. 296, explains $K^{\prime}$ üh as 'clothes made of the fibres of the yellow mulberry.' Where they not the robes made with the silk of the preceding year?

63) Yueh ling, III, 12 ; ibid. p. 265.

65) Li ki, XXI, sect. II, par. 7 ; Legge's translation, p. $2: 3$.

66) Li ki, XXII, 5.--Legge, o.c. p. 239 .-Mencius, (37 -289 в.c.) in his book II. part 2 , ch. III, par. 3, quotes the same passage, in his usual loose manner.

67) She king ; Kwoh fung; Odes of Tchao Nan. VII.

68) Ibid. Ode XIII, 3.

69) Ibid. Odes of Yei, II, 3. 
70) Ibud. Odes of Yung, 1X. 1-3.-The fourth of the Odes of Wei in the same part of the She King, contains an allusion to a lad whocame to exchange cloth or p'u against silk or se; which the critic explains by woven silk and raw silk.

71) Ibid. XIV, Odes of Tsao, II1, 2,

72) She King, Part III, div, 3, Ode II, 9.

73) She King, Part. II, div. 1, Ode III, 3.

74) She King, Part. IV, div. 1, sub. div. III, Ode VI1.-Edward Biot in his valuable Recherches sur les mours anciennes des Chinois, d' après le Chi king, 1843, states that in Shensi the King of Ts'in wore a garment of fox-fur; with one of broidered silk over it, and refers to I. xi. V; butthe expression used is simply金帛货kin $y$, broidered robe, without reference to the material of the cloth. The Ode I. iii. XII, also quoted as showing that similar garments of fox-skins were worn at the court of P'ei by the officers, does not speak of silk at all. 75) I. xix. 7, XX.

76) I. x. One IV.---J. Legge, Chines Classics, vol. IV, p. 179 note

77) Ode III, 1 of I, viii.

III.

Variuds tutelary Spirits and Goddesses of silk and Silkworms.

29. No allusion is made to the invention of silk among the many disclosures attributed to the early rulers in the great a ppendice to the Y h-king where a not unconsiderable amount of ancient lore has been piled up. The authorship of the document is attributed to Confucius, and it would have been pencilled down by one of his disciples.

The same silence occurs in the varions fragments of olden times which have been added to the Book of $\mathrm{M}$ ont ain s and S e as, under the Han dynasty.

30. But if there is no allusion to the invention of silk in these ancient documents, thessame condition rather ominons exists no morein late works. The $L i k i$ or $\mathrm{Record}$ of $\mathrm{Rites}$ has a curious passage sketching a period of savage life in the history of the people ${ }^{78}$.

"Formerly the ancient kings had no houses. In winter they lived in caves which they had excavated, and in summer in nests which they had framed. They knew not yet the transforming power of fire, but ate the fruits of plants and trees, and the flesh of birds and beasts, drinking the blood, and swallowing the hair and feathers (as welli. They knew not yet the use of flax and silk, but clothed themselves with featlers and skins.

"The later sages arose, and men (learned) to take advantage of the benefits of fire. They moulded the metal and fashioned clay, so as to 
rear towers with structures on them, and houses with windows and doors. They toasted, grilled, boiled and roasted. They produced must and sauces. They dealt with the flax and silk so as to form linen and silken fabrics.

No deity, or presiding genius of silk culture seems to have been known at the time of the foregoing text.

31. It is howerer in the same work that a statement which has been expurgated from the received edition, refers to the Sien 'Ts'an (580-9628) as Tutelary Genii in the following terms : "ln the first month of spring ..... the Hou fei, i.e. the wife of the King or Prince, after having fast of animal foud, offers a sacrifice at the Sien $T s^{\prime}$ an or First Silkworms, \&c."The passage is quoted in a cyclopedia of the Xth century ${ }^{79}$. And a gloss in the same work explains Sien $T s^{\prime}$ an by $T^{\prime \prime} i e n ~ s z e^{80}$, the quadriga of heaven which consists of four red stars of the Scorpio; this was one of the many names of fang the fourth of the 28 zodiacal eonstellations, and the most important of spring. Jt was looked upun as announcing the fortheoming harrest. The commentary is important as it tends to show that Sien I't'an was not a proper name and simply an appellative of season. And the statement does not say to which tutelary god or spirit the sacriffce was offered. We do not find however confirmation of this identification of the $Q u$ adriga-of-heaven with the Sien Ts'an in any of the many apuellatives of that group of $\operatorname{stars}^{81}$. The commentator was ill-informed, or the appellative was a popular one which has not found its way in astronomical literature. It is only the Niü si $\bullet$, the third constellation of winter which shows some references to silk culture. A secondary star-group within, the $F u$ Kwang or $\mathrm{T}$ he $\mathrm{B}$ asket-with-h andles is said by the Book-o f-Stars to preside at the rearing of silkworms ${ }^{82}$. As the Book.of-star s although based. upon an older work of the same title, has been recast at the time of the T'ang dynasty (618-906) the selection of this presiding star-group may be not much older than that period. It does not appear in the short list of stars given in the Er-ya of the Confucian era.

32. Another interesting statement concerning the part played by the Enperor himself with reference to the Sericulture is made by Tchang Vhwa (232-300 A.D. ${ }^{83}$ ), in his 'Records of remarkable things,' where he states that in the first months (of the year) of the Tchou, the $\mathrm{Ti}$, or Emperor, did make the census of the silkworms, and presented it with the proper sacrifice $(t s)$ to the tutelary deities of the land (shè) that they would be favorable to the seeds of the silkworms ${ }^{84}$. 
No reference is made in these quotations of ancient times to any special god or goddess of silkworms. They only show how great was the importance attached by the government to sericulture. We see by the $T c h o u-l i$ and the $L i k i$ that there was in the capital a state Magnanerie in olden times. The infererce is not deprived of evidence. A description $^{85}$ of the public buildings in Tchang-ngan, the ancient metropolis during the Han dynasty mentions a kien kwan or cocoonery within the $\mathcal{V}$ grounds of the Shang-lin park, and a 'san sheh or silkworms' house which gave its name to a street of the capital.

33. We cannot positively say that the state inauguration by the Queen and Empress of the silkworm season, which is regulated by the two rituals, we have quoted, was solemnized regularly and without intercepsince Antiquity. But there are occasionally statements about it.

Iu the Dynastic Annals of the Tsin dynasty ( $265-419$ P,c.) Section of Rites, we find stated that the Limpress drove to the silkworm mansion in the Park of the eastern suburb and sacrificed to the (God or God dess of silkworms (9628-705), Tsan shen ${ }^{86}$. We know that the Empress of Kang-ti (343-344) renewed the observation of ancient rules ${ }^{87}$, the silk-worm ceremony was probably one of them. Who was then designated as the goddess of silkworms does not appear. It may have been one of those whose names appear in latcr statements. (Cf. $\$ \S 37,38$ ).

34. Under the Sung dynasty of the $V$ th century, in the reign of Hiao Wu ti, year 460, there is a special entry in the Dynastic Annals stating that the Empress, in the thrd month ordered that the ceremony of feeding the silkworms should be solemnized, and was herself present ${ }^{88}$.

Whatever may have been the temporary breaks in the celebration, we have seen that the ceremony is still solemnized now a days.

35. The T'ung kien kang muh or Synåpsis of history, states that several Empresses, after the time of Si-ling she gave their patronage to sericulture, but it does not substantiate the statement. The probabilities are that the silk industry was indeed taken care of by the soverign and his queen, but no personal names are quoted with or without prominence with reference to it ${ }^{89}$.

35. Sericnlture was then and has remained since a national industry of paramount importance. But no reference occurs in any of these quotations from the classics as to whom was the creator or at least the teacher of the industry for the Chinese. Doubts seem to have been cntertained, by the people, about the departed personage, who in her life time had taken, more than any other, interest in the matter and whose 
the spirit was presiding over the silkworms rearing and silk industry. $\checkmark$ One thing only was certaiu. As it was a feminine occupation, the tutelary deity could not be a man.

37. In the Vth century, Tch'en-yoh a celebrated scholar in a curious work now lost, called The harmonious Record of Ts'i, an extract of w : ich I find in a cyclopedia of the Xth century, makes a distinct reference to a tutelary goddess of silkworms. He says that: "In the middle of the first month (of the year, the spirit (7025 shen) comes down to the grave of Tchen she (11788-4820). She is our own Tutelary goddess of $v$ silkworms and kuows to appreciate the sacrifices (offered to her ${ }^{90}$ ). - Now Tchen she was the family name of the first wife of $\mathrm{Wu}$-ti the great ruler of the Han dynasty ${ }^{91}$, who had married her before he ascended the vthróne, 140 в.c. This is, as far as I am aware, the oldest statement quoting a proper name for that deity.

38. We must come to a much later time to find onother instauce. Lo-yuen of the XIIth century, in his work called Er-ya $y$ or W ing s of the Er-y a, states simply: Now the Tsan shen, i.e. spirits of the silkworms, are two, and called YUEN YÛ fu jin and YÛ SHE kung $t c h u^{92}$. No information as to the identification of these two persons is given therein. but the description words which follow each name are most precise. Fu-jin means simply the wo man and Kung-tchu is a term apply to the daughters of the Royal House since centuries before the Christian $\mathrm{era}^{93}$. There is no intrinsic evidence that these deities were ancient. It is improbable that these two names should be impersonations of the spirits of all the women and Royal or Imperial $P$ rincesses, who by duty bound, and from olden times had attended the rearing of silkworms.

39. They refer more likely to some once renowned females for their devotion to silk culture, whom we know perhaps under different names. The Imperial princess $Y \ddot{u}$ she is ppobably the heroine of the following story :

In the first part of the second century of our era a Chinese princese of the Imperial house ${ }^{94}$ was married to Vijayajaya, the king of Khotan.95 On the demand of her future lord as formulated by a special messenger who informed her that his country had neither silk nor silken stuffs, she secretly procured the seed of the mulberry and silkworms' eggs, and concealing them in her headdress, was thus enabled to escape the search of the guard at the frontier. ${ }^{96}$ It was then strictly forbidden to carry any out of the country. Her difficulties, however, did not finish there. ${ }^{97}$ - 
Once in her new country, the Princess-queen began to raise silk-worms at Ma-dya, situate south ef the capital. But the Chinese delegates seeing: this, led the king to believe that these worms would become venomous snakes which would ravage the land. Vijayajaya gave orders to have the snake-raising house burnt down. The queen, however, managed to sare some and reared them secretly; after a time she had procured silk and could wear silk garments which she showed to the king, who regretted what he had done, and henceforth favoured the silk culture.

Unhappily for the proposed identification, we are not in a position to carry it positively further, as we do not know the exact name of the princess. The Bstan-hgyur gives it as $P u-n y e-s h a r$, which may mean the house-wife of the east, and therefore is no name. On the other hand, Hiuen-Tsang, the Buddhist pilgrim speaks of Lu-shi, litt. stagpierced, as the convent founded by the above Princess-queen, and this name has been gratuitously supposed to be hers, or as the meaning does not fit, a transliteration of it. There is, however, an equation of meaning between $P u-n y e$ as house-vife and $Y \ddot{u}$-she which suggests the idea of a person residing, the resident. Such is apparently the clue to the identification.

As to the other goddes:, Füan yu kwei jin. we have no clue about her; she may have been a Lady-in-waiting to the above Princess. Acting on this suggeston Iüan would have been her name, and Yü liwei jin would be her description as a woman of $Y \ddot{u}$, which was the name of a district in the north of Shen-si under the Han dynasty. ${ }^{98}$ "The fact that they were worshipped and enumerated together must be taken. into consideration, and speaks in favour of this riew.

40. It is important to remark that in none of the statements here collected, no reference whatever has been made to the part attributed to Si-ling she, alias Lui-tsu, Sien tsan; alias Iuen fei.

Notes- -

78) Liki VII; Li yun, sect. I. par. 8 and 9.-J. Legge, The Li ki, p. 369.

79) 'Tai ping yü lan, Kiv. 925, fol.7.

80) In the Er-ya, sect. of T'ien it is mentioned that T'ien sze is Fang. It consists of $\beta, \hat{\delta}, \pi, \rho$.

ह1) Some interesting remarks on this constellation are giren in $G$. Schlegel : Uranographie Clinoise, pp. 113-115.

82) Sing King.-G. Schlegel, Uranographie Chinoise, p. 205, quoting also the Tien huang hwey tung.

8.) Míayers, Chinese R. M., I. 16.---A. Wylie, Notes on Chinese literature. p. 158. 
81) Poh Wuh tchi.---Tai ping yü lan, kiv. 532. fol. 8.

85) The San fu hwang t'u, anthor unknown but commentated upon by Kwoh-P'oh (276-324 A,D.) Cf. kiv. 6, fol. 6 verso.

86) T'sin shu. Li tchi,--Kang hi tze tien, 142, 18. fol. 71 verso.

87) She is called Kang-ti Tch'u Hwang-höu, and her biography from the T'sin tchung tien shu, is mentioned in T'ai ping yu lan, kiv. 138, fol. 9 verso.

88) Lih tchao Ti W ng nien piao; Nan Peh tchao ; Sung, Hiao Wu-ti, 4th year ta ming.---Tung kien kang muh; De Mailla, tom. V. p. 111.-A quotation of the Sung shu in th. Tai ping yü lan, kiv. 142, fol. 8 states that the Empress, in the said year, presided personally orer six mansions for the gathering of mulberry leaves in the western suburb.

89) De Mailla, O.C. ibid.

90) Tcheng, yueh p'an yu shen kiang Tchen she tchi tcheh yun, wo she tsan shen neng kien tsih. Cf. Tai ping yü lan, kiv. 825, fol. 4 verso.

91) Cf. Tsien Hun shu, biography of Hiao Wiu Tchen hwang höu; Tai ping yiu lan, kiv. 136, fol. 4.---Szema Tsien, She ki: biogr. of Tehen hwang höu; kiv. 49, fol. 10.

92) Kin Yuen Yüfu jin Ÿ̈ she kung tchu $K$ 'ang hi tze tien, key $142+18$, fol. 71 vers. On yuen as a proper name ef. $140+5$ fol. 12 vers.

93) It occurs for instance in the commentary of the Tchun tsiu by Kungyang in the third century B.c. Cf. Tai ping yülan, kiv. 152, fol. 1 verso.

94) Named Pu-nye-shar a ccording to the Bstan-hgyur, vol. 94(u) Liyul-gyi Lo-rgyus-pa, fol. 433a: Woodville Rockhill, The early history of Li-yul (Khoten) forming chap, VIII of his work, The Life oj the Buddha. from Tibetan sourees, 18\&4, p. 238.

95) Cf. A. Rémusat, Histoirc de la ville de Khotan, p. 53.-De Rosny, Traité de l'education des vers à soie au Japon, 1869," says 419 of our era, which seems too late by far, as th event happened under the 11 th reign after Tijayasambhara, who ascended the throne of Li-yul or Khotan (Chin. Li-kwei, Jiu-tien) 165 years after the foundation of Liyul. The latter erent is fixed by Tibetan sources at 234 years after Buddha's Nirrana (477 в.c.) or in 248 в.c. Therefo.e $185+24 \mathrm{C}$ (= 12 reigns of 20 aver.) wou'd lead to 162 A.D.

96) As recorded by Hiuen-tsang, the Buddhist pilgrim,-S, Beal, Si-yukí, rol II. p. 319.-Stanislas Julien, Voyages des Pelerins Bouddhistes, rol, III. p. 238 .

7) The following comes from Tibetan sources, in W. Rockhill, Op. cit. p. 239.-Fa-hien the Chinese Buddhist pilgrim, circ. 400. mentions silk in Khotan; cf. S. Beal, Si-yu-ki, vol. 1. introd. p, 26.- The $\mathrm{C}$ nsse annals Peh-she (386-581) mentions mulberry trees in the same country. Cf. Tai ping yü lan, Kiv. 792, fol. 6 .

98) Cf. Playfair, The cities and towns of Chrna, No. 8819. 


\section{IV. \\ Formation of the Legend of the Godess "Si-ling she" the Grand-muther of Thread.}

40. When Szema Tsien and his father compiled in the second century B.c. the materials of the She $i k$, they came across documents giving to the first wife of Hwang-ti the traditional name of Lui tsu 委累 祖 which they reproduced accordingly in their history ${ }^{99}$, without any intimation as to the possible meaning which could be inferred from the ideographical value of the symbols composing that written name. It seems that previously the first symbol was simply written 黑: and that the additon of the determinative $\mathrm{wo} \mathrm{man}$ was their own, ${ }^{100}$ according to a practice then current to aroid misconceptions The simple symbol was phonetically employed as a proper name and its meaning was left rague and undefined. Nothing is said by the Szemas as to the spinning and weav- ? ing inventions attributed in after ages to Lui tsu and her lord.

41. But subsequently when rationalists began in the following centuries to ponder over the shreds of record, saved from the remotest times, they endeavoured to real behind the written words and to guess through the ideographical meanings inherent to the characters of the writing, statements hitherto hidden to view. The result was to see that the original meaning of 䍗 lui, to bind was that of thread, and therefore that the name of Lui 女罢 once deprived of the determinative of wo man its latest adjunct ${ }^{101}$, and combined with 㼛, $t s u$, grand-p a r en t, was obviously the depository of a tradition hitherto concealed from the gaze of former historians. The notion that the first wife of Hwang-ti was the grandmother-of-thread was thus revealed, and forms an interesting instance of script-myth, a phenomenon which has not as yet received its shire of attention from the investigators of the history of culture among populations having a hieroglyphic or ideographic writing. This supposed information entailed the formation of a popular legend making the wife of 
the first ruler necessarily busy with the silkworms, like so many other housewives in the silk-producing provinces, and the queens of former kings, as shewn and regulated by the traditional rites.

42. But I do not find the fact given as historical before Lin Shu, the collaborator of Szema Kwang, anthor of the Tung lien, published in 1080. This writer compiled a history, much esteemed and entitled Wei $k i$, from the most remote times, in which his purpose was to record all that is not stated in the classics. ${ }^{102}$ and where we find the following statement: 103

"Siling she, the Empress of Hwang-ti, began to rear silkworms:

"At this period Hwang-ti invented the art of making cloth."

And thus has grown the legend which since has been looked upon as genuine history.

43. None of the classies and historical works which we have referred toin these pages, has any meution of Siling-she, alias Lui-tsu or grandmother of thread, alias Sien ts'an or ancient silkworm, alias Yuen fei or firstwife, as the goddess of sericulture. The Si'en Ts'an which are referred to in a spurious passage of the $L_{i} l_{i} i$ which we have quoted in a previous paragraph (3I), were not understood then as applied to the silkworms reared by the first wife of Hwang-ti, neither by a trope of speech to this fabled personage. The oldest reference to worship of such a goddess is that of the Tsin dynasty, probably in $\checkmark 344$ A.D., but then no name is given, and we have found reason to believe that Si-ling she was not the deity worshipped ly the Tsin Limpress. Her legend was still in a state of formation. It had not yet reached a sufficient degree of authority, and as a fact was not to reach for nearly eight centuries the official standing from which the personality of the Grandmother of thread imposed itself on the Imperialat tention, with deification and worship as a natural consequence, and the annual state sacrifice (of the present time.

44. The claims of Hwang ti and his Queen to the honour of being the first silk culturists are looked upon as little established even by Chinese writers: Hwan Tan, for instance, went so far as to suggest that an earlier ruler Shen-nung, the Mythical husiandman Emperor, was really the first who had ever made a $h^{\prime}, n$ lute in t'ang. wood, and twisted silk for the strings. ${ }^{104}$ The suggestion, of cuurse, is ralueless in itself, but it shews the little confidence of some Chinese in the story of Siling-she.

45. Lui-tsu is said by the traditional history to have been a daughter from the clan of Si-ling; the name heing at the same time that of her 
native eountry. We may as well state here, previonsly to any enquiry, that there is no possible conneetion between this Si-ling and the s' $i$-ling, ipsis litteris, which was the name in Hup eh, ${ }^{105}$ applied under the Han dynasty, to the region of the Mu-ling range of the present day in the N.E. of the province. As it was substituted only at that timefor several names whieh were different before, there is no possibility of any conneetion with the personal name of Yuen-fei.

As a faet $S i$-ling, meaning literally $W$ est hill s, 106 might not suggest any speeial region, and may have been applied to a mountainous tract anywhere provided it be eonsistent with the geographieal location of the interested writer. The matter requires a greater preeision than $\pi$ fliave hitherto found in the statements quoted on the subjeet.

46. The Si-ling name of the original eountry of Lui-tsu, has not yet been identified, and therefore we may as well make an attempt at elncidating this point of mythieal geography, and enquire as to the possibility that it should really indieate a region where silk industry was already in existence before the arrival of the Chinese Bak tribes. It would be quite in the natural order of things that the Chinese leader should have married a daughter of the eountry, who being aequainted with the industry of her native land, should have taught the rearing of silkworms and the winding of the silk to the followers of her lord and master. Unhappily for the veraeity of the legend, serieulture was not known in Si-lir.g.

47. In the Er-ya, seetion of the land $\mathrm{d}^{107}$, the aneient lings are briefly indicated thus: the Tung ling or East hils are Sin ${ }^{108}$; the Nan ling or South hills are the Sil shen ${ }^{109}$; the $s_{i}$ ling or West hills are the Wei barbarians (which we shall refer to hereafter); the Tchung ling or Central hills are the Tchu t'eng; the Peh ling or North hills are the IVest Yiu, it is the $Y e n$ gate (in N. Shansi).

48. The Wei barbarian ${ }^{110}$ mentioned therein are known in other works, and their settlements were in the immediate south of the present department of $\mathrm{T} \operatorname{sing} \mathrm{g}$ ing in S. E. Kansuh ${ }^{111}$, The information is consistent with that derived from the Book of Mountains and Se a s, whieh shows that the Si-ling or western hills of the story were to be sought for in the mountain ranges of the North-west. And as these mountains, being simply the spurs of the Kuen-lun range, extend eastwards, running from the west and passing at proximity of the Heh shuil12 of the story, the identifieation is sufficiently aeeurate in its broad lines, and we cannot expect a greater precision in a statement of legendary giograpiny. 
49. But lad the legend any slight foundation like that we have suggested, $\S 46$, it must have lingered in popular minds quite outside the range of literature. The fact does not seem improbable, as records of this folklore and belief may have disappeared in one or the other of the five great bibliothecal catastrophes which have made of the ancient literature of China a mere wreck. However the hypothesis seems difficult to maintain with the positive statements and allusions we have collected which show vagueness of former beliefs about the protective genii of silk and silkworms. Moreover, the geographical information gathered in the first part of this paper ( $\$ \S 3-21$ ) show reason to believe that silkworms did not exist in the N.W. of China until later times, and therefore that during the period of their earliest settlements in Kansuh and Shensi, the immigrating tribes under the leadership of Hwang-ti, who married a girl of Si-ling in that region, cannot have been made acquainted by her with the art of sericulture.

\section{Conclusion.}

50. The onteome of the foregoing paper, about the history and legend of Si-ling she as the real inventor of the silk industry, is that they have no historical fouudation. It is another instance of the ways and means which have contributed to the formation of the modern Pantheon of the Chinese. In the few ancient accounts of innorations and inventions attributed to the lulers of the legendary period, such as Hwang-ti and others, accounts which are found in the great Appendix to the Book of Changes, ${ }^{113}$ the authorship of which is attributed to Confucius through the pencil of a disciple, and in the fragments of older times added to the Buok of mountains and seas ${ }^{114}$ during the Han period, no allusion whaterer is made to the invention of the silk industry. This silence, to say the least, is very significant, as it concerns a mogt ancient and most prominent industry of China which was entitled to a special mention should the legend attributing its inrention to $\mathrm{Hwang-ti}$ and his wife hare existed at the time when these accounts were compiled. It may be taken as a concurring and final proof that silk culture was not a Chinese invention, and was proper to the pre-Chinese populations of the country, particularly in the east, as shewn by the geographical and historical data collected in these pages.

The whole evidence concurs to show that it was only when the civilised chieftains of the Bak families arriving from the West, advancedeastwards and intermarried with girls of the native tribes, that they became acquain- 
4 with the sericulture which was in after ages looked upon in their traditions as special to their primitive wives in the country wihout geographical distinction between the west and the east of the Flonesy Land.Aud it was in comparatively recent times that attempts were made at fostering a legend of invention of the sericulture on some special personage of history.

\section{Notes- -}

99) She ki, kiv. I, fol. 5.

100) It does not anyhow go further back than the siao tchuen, which is the style of writing employed during the last centuries preceding the Christian era. Iu ny note on The Oldest Chinese Chracters: The Academy, June 15, 1889, p. 416, I lave given occasionally the history of this style of characters.

101) On the late adjunction of deteminatives in many cases, cf. S.W., Bushell : The Stone drums of the Chow dynasty, 1874: T. deL. The oldest Book of the Chinese, $\$ 25, \mathrm{n} .3$; Introduction to Historical Catulogue of Chinese Money, part VI,

102) Cf, De Mailla, vol I Preface, p. xlv.

I03) Cf. Wells Williams, Midrle Kingrom, vol. II, p. 32.

104) Hwan Tan, Sin lun. Tuen Kien lui han Kiv. 366, fol. 22.-Tu pıng yü lan, Kiv, 814 , fol. 3.

105) Cf. in G. Playfair, Cities and towns of Chin\%. Nos. 2426, 2432 $2658,4731,8925$.

106) The Er-ya says: ' a great mound is called a ling ; ta fou yueh ling.

107) Er-y, tcheng wen tcheh yn, ed.1861; II. 9.

108) Position and meaning unknown in geography.

109) This is a known rariant for the name of the Djurtchen. Cf. my paper on The Djurtchen of Manidshuria, par.3. But I do not know any other document stating their advance in ancient times southwards at it sufficient proximity to a hill-range, which could be under any aspect looked as south of the ancient Chinese. I am afraid an error niust have crept in there. The character sher may have been mistaken for tchéng town as there was asmall state of that same name, $S i k$, in Honan, mentioned in the Tsotchuen, Duke Yn. year XI, which by its position answers. the requirement pretty well.

110) The term used is $\mathrm{Y}$ in the first case, and $\mathrm{J}_{\mathrm{CNG}}$ in the second; but the distinction which their difference conveyed in former times was lost when that part of the $E r-y a$ was compiled.

111) Cf. Playfair, The Cities and towns of China, Nos.7978 and 1183. Tsing-ning, lat. 55035'; long. 105045'.

112) Namely the Etsina river, east of Su-tchou in Kansuh, which from the slopes of the Nan-shan range runs nortliwards to the small lakes called $S$ ob o nor and Sogok nor.

113) Yh-king; hi-tze., pt. 2.

114) Shan hai king, Bk. 18. 
Errata:-

$\$ 1,1.3$, for ts'en tsan tao read sien ts'an tao

"5, 1. 13, for oldest read eldest

"8, 1.3, after spoken of read: as there was no occasion to make a distinction between the $w u$ and kung (cf. \$15).

9 9, 1. 6, for trings read strings.

"12,1.1. for King-tca u read King-tchou

, 15,1.7, for no silk read no silk

"I8.1.8, for that silk was read that silk only was

"19. 1.6, for of Shensi read of in Shensi

几 Note 18, for fiłe different read five different

, 26, for K'iuson read K'iusuu

"39, for $\mathrm{Pa}-$ read $\mathrm{Pau}-$

"47, for devided read dirided

$\$ 27,1.11$, for pennows read pennuns

" 31, 1. 12 for Tt'an read I's'an

", 38, 1. 8, for apply read applied 


<smiles>CCCC</smiles> 
